\title{
Etika Profesi Bimbingan dan Konseling: Konseling Kelompok Online dan Asas Kerahasiaan
}

\author{
Diana Syamila*, Happy Karlina Marjo \\ Program Studi Magister Bimbingan dan Konseling, FIP Universitas Negeri Jakarta \\ *Corresponding Author. Email: DianaSyamila_1108820001@mhs.unj.ac.id
}

\begin{abstract}
The purpose of this study was to discuss the ethical role of the guidance and counseling profession, especially the principle of confidentiality in the implementation of online counseling. This research method uses a descriptive qualitative literature review that examines several scientific articles accompanied by the results of interviews and previous research results. The data analysis technique uses descriptive analysis techniques. The results of this study explain that counselors have an ethical responsibility to explain the meaning of confidentiality in group counseling. The principle of confidentiality is important considering that the professional ethics of the counselor pays more attention to the privacy of the counselee, because it will involve comfort and security in receiving counseling services. In the implementation of online counseling, counselors can anticipate the possibility of unwanted violations by making efforts such as: (1) Conducting interviews and evaluations when forming groups, (2) Conducting in-depth observations when providing classical services in the classroom, (3) Grouping individuals who voluntarily and voluntarily participate, (4) Giving informed consent containing personal data, applicable rules, and cooperation agreements, (5) Members affix their signatures on the under a statement about what they will accept if they do not fulfill it.
\end{abstract}

Abstrak: Tujuan penelitian ini adalah untuk membahas peran etika profesi bimbingan dan konseling terutama asas kerahasiaan dalam pelaksanaan konseling online. Metode penelitian ini menggunakan kajian pustaka yang bersifat kualitatif deskriptif yang mengkaji beberapa artikel ilmiah disertai hasil wawancara dan hasil penelitian sebelumnya. Teknik analisis datanya menggunakan teknik analisis deskriptif. Hasil penelitian ini menjelaskan bahwa konselor memiliki tanggung jawab etis untuk menjelaskan makna kerahasiaan di dalam konseling kelompok. Asas kerahasiaan menjadi penting mengingat etika profesi konselor cukup memberi perhatian lebih perihal privasi konseli, sebab akan menyangkut pada kenyamanan dan keamanan dalam menerima layanan konseling. Dalam pelaksanaan konseling online, konselor bisa melakukan antisipasi tentang adanya kemungkinan pelanggaran yang tidak diinginkan dengan melakukan upaya seperti: (1) Melakukan wawancara dan evaluasi ketika membentuk kelompok, (2) Melakukan observasi secara mendalam saat memberi layanan klasikal di dalam kelas, (3) Mengelompokkan individu yang secara sukarela dan tidak sukarela, (4) Memberi inform consent yang berisi data diri, aturan yang berlaku, dan perjanjian kerjasama, (5) Anggota membubuhkan tanda tangan di bawah pernyataan tentang hal apa saja yang akan mereka terima apabila tidak memenuhinya.

\section{Article History}

Received: 07-12-2021

Revised: 14-12-2021

Accepted: 24-12-2021

Published: 07-01-2022

\section{Key Words:}

Professional Ethics, Online Group Counseling, Confidentiality.

\section{Sejarah Artikel}

Diterima: 07-12-2021

Direvisi: $14-12-2021$

Disetujui: 24-12-2021

Diterbitkan: 07-01-2022

\section{Kata Kunci:}

Etika Profesi, Konseling Kelompok Online, Asas Kerahasiaan.

How to Cite: Syamila, D., \& Marjo, H. (2022). Etika Profesi Bimbingan dan Konseling: Konseling Kelompok Online dan Asas Kerahasiaan. Jurnal Paedagogy, 9(1), 116-123. doi:https://doi.org/10.33394/jp.v9i1.4527

\section{Pendahuluan}

Terjadinya perubahan pesat di dunia pendidikan saat ini dipengaruhi besar oleh teknologi yang mengharuskan segala kegiatannya dilakukan secara jarak jauh. Teknologi dalam konseling mulanya digunakan sebagai media untuk mempermudah konselor sekolah dalam mengumpulkan, mengolah, dan menganalisis data untuk menunjang kegiatan 
pemberian layanan. Selain itu, teknologi juga digunakan sebagai alat pemberian informasi terkait hal-hal yang menyangkut kesehatan mental, cara menangani, jenis-jenis masalah, sampai bagaimana peserta didik dapat memperoleh bantuan (Gozali, 2020). Namun dewasa ini, sebagai guru termasuk konselor, penggunaan teknologi menjadi hal yang niscaya dan merupakan sebuah tuntutan untuk mahir memanfaatkan teknologi (Haryati, 2020).

Strategi pemberian layanan di era teknologi memerlukan inovasi yang efektif agar para calon konseli secara sukarela meminta bantuan layanan konseling, sehingga konseling online menjadi hal yang wajar dilakukan. Menggunakan teknologi yang dalam pelaksanaannya dilakukan secara jarak jauh, menimbulkan perdebatan sebab kekuatan utama dari proses konseling adalah bahasa tubuh yang akan membantu konselor memberi analisis secara objektif. Namun di sisi lain, pemanfaatan teknologi dengan melakukan konseling secara online memiliki beberapa kelebihan berupa efektivitas waktu, tenaga, dan biaya (Syamila \& Herdi, 2021) baik bagi konselor maupun konseli.

Kelebihan dan kekurangan pelaksanaan konseling secara online berkaitan dengan isu etika profesi bimbingan dan konseling yang dalam pelaksanaannya, akan menimbulkan situasi dilema bagi seorang konselor, dimana teknologi juga dapat menjadi ancaman bagi penggunanya terkait kerahasiaan data (Walz \& Kirkman, 2004). Konselor dalam memberikan layanan memiliki asas kerahasiaan sebagai pembeda dirinya secara professional, dimana secara etis konselor diwajibkan menjaga kerahasiaan seluruh hal yang menyangkut harga diri konseli (Corey, Corey, \& Callanan, 2011). Dengan adanya layanan konseling secara online, asas kerahasiaan menjadi ancaman bagi konselor sebagai professional (Ardi \& Putra, 2017).

Penelitian dengan memanfaatkan teknologi dalam pelaksanaan konseling online memiliki hasil yang positif melihat bahwa beberapa kelebihan dirasakan oleh konselor dan klien, walaupun beberapa ahli menyebutkan bahwa pelaksanaan konseling online menjadi perdebatan dan rentan bagi konselor untuk melanggar etika profesi, terutama etika tentang menjaga kerahasiaan. Pertimbangan etis yang berkaitan dengan kerahasiaan dan efektivitas konseling online tidak dapat dilakukan secara etis melalui internet, kecuali dalam keadaan yang sangat terbatas, sebab melindungi privasi dan kerahasiaan klien adalah hal yang sulit dan secara pasti individu tidak dapat diidentifikasi secara spesifik (Humphreys, Winzelberg, \& Klaw, 2000).

Penelitian ini melakukan wawancara mendalam kepada guru Bimbingan dan Konseling (BK) di Jakarta dengan topik isu etika bimbingan dan konseling di masa pandemi. Penelitian ini mengangkat topik tersebut untuk mengetahui bagaimana etika profesi bimbigan dan konseling mempengaruhi guru BK dalam memberikan layanan serta kendala apa saja yang dihadapi. Wawancara dilakukan melalui aplikasi Zoom, hasil data diintegrasikan dengan beberapa jurnal untuk kemudian dijadikan sebuah kesimpulan serta solusi dari permasalahan yang diangkat dalam penelitian ini. Adapun tujuan penelitian ini adalah untuk membahas secara rinci bagaimana peran etika profesi bimbingan dan konseling, terutama asas kerahasiaan dalam pelaksanaan konseling online. Sehingga, upaya-upaya apa saja yang bisa dilakukan bagi seorang konselor untuk tetap menegakkan asas kerahasiaan dalam pelaksanaan konseling online.

\section{Metode Penelitian}

Penelitian ini menggunakan metode kajian pustaka yang bersifat kualitatif deskriptif dengan mengkaji berbagai jurnal ilmiah dengan menginterpretasi kumpulan artikel-artikel lain sebagai kajian literasi, yang dikuatkan dengan data hasil wawancara mendalam dengan guru 
BK di SMA Swasta Jakarta. Selanjutya data yang diperoleh dianalisis dengan teknik analisis deskriptif.

\section{Hasil Penelitian dan Pembahasan Konseling Kelompok Online}

Kelebihan dan kekurangan konseling online menjadi kontroversial di beberapa diskusi terkait etika profesi tertulis profesi konseling. Namun dewasa ini, konseling online sudah mulai terlihat kelebihannya secara signifikan apabila melihat efektivitas pelaksanaannya. Bagi sebagian individu, konseling online dapat membantu individu sebab lebih kecil kemungkinan bagi dirinya merasa terintimidasi apabila harus bertatap muka langsung dengan konselor (Tsan \& Day, 2008). Selain itu, dengan maraknya penggunaan teknologi secara massif membuat layanan konseling secara online dapat mudah ditemukan, sehingga anggapan bahwa mencari bantuan konseling yang membuat stigma negative di masyarakat dapat berkurang dengan adanya layanan online.

Terdapat beberapa jenis layanan konseling online yang dapat ditemukan secara mudah oleh individu seperti website (Prahesti \& Wiyono, 2017), pesan teks cepat (Duniawati, Muksin, \& Lukman, 2020), telepon (Masi \& Freedman, 2001), konferensi video (Prabawa, 2015), Instagram (Noviyanti, 2020), atau website yang dikembangkan sendiri (Prabawa, Ramli, \& Fauza, 2018). Beberapa platform ini sudah dibuktikan efektif walau terdapat kekurangan dalam pelaksanaannya.

Konseling kelompok online yang dilakukan oleh seorang guru BK dan wali kelas sebuah sekolah menengah pertama (SMP) dengan isu pertemanan remaja yang disebabkan oleh kesalahpamahan antar anggota terjadi di tengah-tengah situasi mereka yang seluruh kegiatan dan komunikasi hanya bisa dilakukan jarak jauh (Syamila \& Herdi, 2021). Artinya, kesalahpahaman di dalam pertemanan remaja, khususnya peserta didik kelas 7 ini disebabkan oleh teknologi dan sosial media. Sehingga, guru BK melakukan konseling online dengan berbekal perjanjian dan aturan yang telah bersama-sama disepakati secara lisan. Pelaksanaan konseling online dengan melakukan tahapan-tahapannya memiliki hasil yang efektif dan mencapai tujuan. Beberapa peserta didik bahkan ada yang memberi kesan agar merekomendasikan peserta didik lain yang sedang mengalami permasalahan serupa secara kelompok.

\section{Etika Profesi Konseling Kelompok Online}

Bagaimana seorang konselor dapat berpartisipasi secara etis sebagai fasilitator dan penasihat dalam kelompok berbasis internet? Etika profesi menjadi hal yang bisa menimbulkan perdebatan dalam pelaksanaan konseling kelompok online. Dewasa ini, pertumbuhan yang pesat dari teknologi internet dan kelompok online telah melampaui perkembangan pedoman etika formal bagi konselor yang terlibat di dalam kelompok online (Humphreys, Winzelberg, \& Klaw, 2000). Konselor memiliki kewajiban untuk memberikan informasi tentang kualifikasi, kompetensi konselor dan informasi penting lainnya kepada anggota untuk menekankan komunikasi terbuka agar tumbuhnya kedinamisan di dalam kelompok (Ardi \& Putra, 2017).

American School Counseling Association (ASCA) telah mengeluarkan pernyataan singkat tentang etika yang berhubungan dengan internet, namun belum ada pedoman komprehensif untuk perilaku etisnya (Humphreys, Winzelberg, \& Klaw, 2000). Sehingga dalam pelaksanaannya beberapa professional memilih untuk memakai strategi sendiri berdasarkan pengalaman dalam mengorganisir, mengevaluasi, dan menasihati kelompok online (Klaw, Huebsch, \& Humphreys, dalam pers; Lieberman et al., 1999; Winzelberg et al., 
1998, dalam pers). Proses adaptasi ini tentu akan melibatkan secara besar bagaimana kerahasiaan dan privasi individu terjaga sesuai dengan etika profesi yang berlaku.

Dalam interaksi tatap muka dengan kelompok, peran dan tanggungjawab etis konselor lebih mudah ditetapkan, dijelaskan, dan dipertahankan. Misalnya, konselor dapat melihat dengan jelas siapa yang sedang mendengarkan dan menyimak apa yang dikatakan, mengumpulkan dan menjawab pertanyaan, dan mengulangi prosedur bagi pendatang baru atau anggota kelompok yang terlambat. Berbeda hal dengan konseling kelompok yang dilakukan secara online, konselor akan mengalami kesulitan sebagai koordinatir, konsultan ahli, atau peneliti sebab mereka harus memiliki asumsi bahwa setiap tindakan yang diambil dalam kelompok dapat berpotensi mengubah hubungan peran dan tanggung jawab mereka. Adanya fitur keluar-masuk bagi anggota ketika berlangsungnya kegiatan memudahkan sekaligus membingungkan mereka tentang aturan yang ada di dalam kelompok, sehingga perlu bagi konselor secara berkala dan terus-menerus menjelaskan peran dan tanggungjawab konselor serta anggota selama kegiatan.

\section{Tabel 1. Strategi Perilaku Etis dalam Kelompok Berbasis Internet Strategi Perilaku Etis dalam Kelompok Berbasis Internet}

(Humphreys, Winzelberg, \& Klaw, 2000)

\section{Peran Professional}

Tidak menyiratkan hubungan terapeutik secara pribadi ketika tidak dapat memenuhi tanggung jawab etis yang menyertainya.

Tetapkan batasan dalam membalas pesan yang masuk, baik melalui pesan pribadi, pesan grup, maupun email (misalnya, konselor mungkin tidak membaca setiap pesan dan tidak memberikan respon sebagai konselor.

Berikan tanggapan berupa saran hanya dipostingan publik yang semua anggota dapat membacanya, agar merangsang mereka untuk berdiskusi serta memberi batasan kepada anggota bahwa segala bentuk interaksi dilakukan secara kelompok.

Siapkan akun terpisah antara email pribadi dengan email yang dibutuhkan untuk kelompok online.

\section{Peran Anggota Sebaya}

Waspada terhadap kemungkinan bahwa konseli, peserta didik, atau rekan kerja mungkin berpartisipasi secara aktif atau "mengintai" dalam group online.

Pertimbangkan untuk menggunakan nama samaran saat ingin memposting.

Kedua Peran

Lakukan penjelasan secara berkala tentang hubungan peran di dalam kelompok online.

Gunakan tanda pesan otomatis yang berisi informasi sesuai dengan peran yang dipilih (professional atau anggota).

Faktor yang mempengaruhi individu dalam mengikuti kegiatan kelompok secara online adalah adanya perasaan komunitas atau keterlibatan sehingga menimbulkan koneksi di antara peserta didik. Komunikasi yang bermakna tercapai ketika peserta didik dapat berinteraksi secara terbuka (Koh \& Hill, 2009). Sehingga terdapat tiga hal penting yang harus diciptakan dalam kegiatan kelompok online seperti kehadiran sosial, komunikasi terbuka, tanggapan kohesif, dan koneksi afektif.

\section{Asas Kerahasiaan}

Komunikasi di internet dapat membuat masalah privasi, kerahasiaan, dan hubungan pribadi yang membingungkan bagi konselor dan konseli. Individu yang mulai menyusun dan mengirim pesan kepada figur yang dianggap konselor sebagai bantuan professional mungkin 
akan merasa bahwa mereka memulai percakapan pribadi yang intim. Namun, adanya interaksi di internet memungkinkan percakapan tersebut berada dalam sebuah ancaman terjadinya kebocoran. Terjadinya kebocoran privasi dapat dilakukan oleh individu yang menyalin ulang percakapan pribadi dirinya kepada orang lain yang tanpa kesadaran mereka, hal tersebut dapat membahayakan dirinya. Demikian pula, dengan konselor yang berniat untuk mendiskusikan permasalahan individu kepada yang lebih ahli namun tanpa disadari, menyalin teks pribadi konseli dapat menimbulkan kemungkinan yang lebih besar tentang pelanggaran etis.

Asas kerahasiaan merupakan kekuatan dari pelaksanaan konseling yang membedakannya dari proses bertukar cerita biasanya. Proses konseling merupakan proses professional yang menciptakan tempat aman bagi individu yang mengalami kendala dengan dirinya atau psikologisnya. Kerahasiaan dalam situasi kelompok tidak mudah ditegakkan, sebab anggota bebas berasumsi atas apa yang mereka dengar di dalam kelompok. Hal tersebut kemudian dapat mempengaruhi anggota kelompok untuk menyaring banyaknya informasi yang akan mereka ungkapkan, sehingga komunikasi terbuka sulit untuk tercipta.

Konselor memiliki tanggung jawab etis untuk menjelaskan makna kerahasiaan di dalam kelompok, pentingnya kerahasiaan, dan memberitahu anggota terkait hambatan dalam menegakkan kerahasiaan di dalam kelompok secara terbuka (Corey, Corey, \& Callanan, 2011). Meskipun konselor diharapkan dapat menekankan pentingnya kerahasiaan di dalam kelompok, konselor juga diharapkan dapat memberitahu anggota tentang batasan dan kelemahannya secara terbuka. Misalnya, dalam proses kelompok salah satu anggota memberitahu tentang hal yang dapat membahayakan dirinya, konselor memiliki kewajiban etis untul mengambil langkah tepat untuk melindungi anggota kelompok.

Kepercayaan konseli mengenai kerahasiaan data yang mereka miliki sangat penting. Hal ini merupakan salah satu aspek yang harus diperharikan dalam memberikan layanan konseling online. Sehingga penting bagi konselor untuk merancang sistem konseling yang menyediakan fitur log-in dengan menggunakan password agar konseli dapat terverifikasi untuk hanya sekadar masuk ke dalam ruang konseling (Ardi \& Putra, 2017).

Adanya layanan yang dilakukan secara online memberi celah bagi individu yang menggunakan akun palsu untuk bergabung pada sebuah layanan, sehingga kebocoran privasi kerapkali terjadi (Kozlowski \& Holmes, 2014). Hal ini akan menimbulkan trust issue bagi anggota lain, sehingga asas kedinamisan di dalam layanan kelompok menjadi masalah lain yang mengikuti.

\section{Analisis Wawancara}

Wawancara dilakukan dengan seorang guru BK SMA Swasta di Jakarta membahas tentang isu etika profesi yang dihadapi melalui aplikasi Zoom Meeting. Dalam pelaksanaan konseling selama pandemi, guru BK menggunakan beberapa aplikasi untuk melakukan konseling jarak jauh, dapat berupa chatting, video call, dan video conference. Layanan yang pernah diberikan secara online salah satunya adalah konseling kelompok. Guru BK menentukan anggota kelompok melalui laporan dari guru mata pelajaran terkait permasalahan yang dialami sekelompok peserta didik.

Konselor seringkali mengalami kendala terkait klien yang terlalu nyaman sehingga merasa bergantung. Mengantisipasi itu, di awal pertemuan konselor menjelaskan peran dan tanggung jawab dirinya dan klien selama proses intervensi. Apabila dalam pemberian layanan klien terlihat sangat menggantungkan dirinya pada konselor, konselor kembali mengingatkan peran dan tanggungjawab tersebut dengan memberi atau mengingatkan kemajuan-kemajuan 
klien beserta bukti-buktinya agar klien kembali bersemangat dan terpacu untuk mulai bersikap mandiri. Penjelasan peran dan pemberian informasi terkait kemajuan yang dimiliki klien secara berkala merupakan hal yang penting dalam proses intervensi agar klien menyadari bahwa potensi dirinya mampu menyelesaikan permasalahan yang dimilikinya sendiri.

Pelaksanaan layanan baik individu maupun kelompok, selalu mengedepankan asas kerahasiaan untuk menjaga kepercayaan dan kenyamanan klien. Untuk menjaga kepercayaan klien, konselor melakukan interaksi yang tidak terputus dengan selalu menanyakan keadaan klien, merespon klien dengan cepat, mengulang kembali hasil pembahasan pada pertemuan sebelumnya agar klien merasa konselor memiliki perhatian yang hangat kepada dirinya, serta tidak bosan memberi apresiasi kepada klien apabila mengalami kemajuan selama proses intervensi sekecil apapun.

Kasus dilematis yang dialami konselor terkait asas kerahasiaan adalah tentang seorang siswi tingkat akhir yang sedang hamil, sedangkan ia sedang menjalani ujian akhir sekolah. Saat itu, konselor merasa dilemma untuk menginformasikan hal ini kepada orang tua dan pihak sekolah apabila memikirkan dampak-dampak yang diterima siswi tersebut apabila pihak-pihak tersebut mengetahui kebenarannya. Langkah yang diambil konselor adalah dengan berkomunikasi dengan klien untuk meminta persetujuan atas rencana langkah yang sudah disusun konselor dengan menginformasikan kehamilannya disertai manfaat-manfaat yang akan diterima dirinya apabila pihak-pihak tersebut mengetahui dan mau berkompromi. Proses komunikasi kepada klien dan pihak-pihak terkait tentu akan menguji kemampuan komunikasi yang dimiliki konselor agar situasi dilematis yang dihadapi mencapai mufakat bersama.

Asas kerahasiaan di era pandemi yang mengharuskan segala sesuatu dilaksanakan secara online juga memberi kendala bagi konselor yang menangani peserta didik dengan adiksi gawai, sebab layanan online akan membuat anak tersebut semakin menggunakan internet dan menjadikan proses pembelajaran sebagai alasan mereka untuk bermain gawai. Sehingga, konselor menurunkan standar progresif bagi peserta didik tersebut yang berbeda dari biasanya. Seperti, layanan dinilai efektif apabila mulanya peserta didik tidak ingin berbicara dengan guru BK, dengan dilakukan intervensi peserta didik tersebut sudah mulai mau berinteraksi dengan guru BK. Selain itu, dengan melakukan layanan konseling kelompok secara online dengan peserta didik yang memiliki adiksi gawai membuat guru BK kesulitan menyampaikan layanan sebab fokus mereka pasti akan terbagi.

Asas kerahasiaan juga menjadi ancaman bagi peserta didik yang sebagian besar memiliki adiksi gawai, sebab kebanyakan peserta didik dengan indikasi tersebut lebih memahami teknologi dan tahu bagaimana menggunakan fitur-fitur di internet dibanding peserta didik lainnya. Hal tersebut tentu mengancam privasi di dalam kegiatan kelompok, seperti informasi-informasi ataupun akun yang tergabung di dalam video conference.

\section{Pembahasan}

Perkembangan teknologi yang semakin pesat tidak diikuti dengan pembaharuan etika profesi konselor. Sehingga sebagai konselor professional, secara bijaksana konselor perlu mengadaptasi etika profesi yang sudah ada. Konseling online memungkinkan privasi konseli terganggu, seperti: (1) Dapat direkam dan disebarluaskan tanpa sepengetahuan konselor maupun anggota kelompok lain dalam layanan kelompok. (2) Isi percakapan di sosial media dapat di capture dan disebarluaskan baik oleh anggota kelompok lain, maupun individu itu sendiri. (3) Adanya banyak fitur menuntut konselor untuk memahami teknologi secara 
menyeluruh, sebab dengan layanan yang dilakukan secara online konselor tidak bisa memantau secara pasti siapa saja yang sebenarnya tergabung di dalam ruangan mereka.

Di antara semua kemungkinan buruk tersebut, dengan tanpa adanya system online, pelaksanaan konseling kelompok juga memiliki kerentanan dalam menegakkan asas kerahasiaan sebab layanan yang dilakukan tidak hanya diberikan kepada satu orang, melainkan beberapa orang yang di dalam pelaksanaannya, konselor tidak bisa mengatur anggotanya untuk menyimpan memori apa saja yang akan masuk di dalam ingatan mereka dan hal apa saja yang bisa disampaikan anggota kelompok di dalam kegiatan mengingat bahwa asas kerahasiaan dan kedinamisan juga ditekankan di dalam kegiatan kelompok. Antisipasi tentang adanya kemungkinan hal-hal yang tidak diinginkan, konselor bisa melakukan beberapa upaya sebagaimana tertulis dalam etika profesi konselor tentang membentuk dan mengelola kelompok (Corey, Corey, \& Callanan, 2011) dimana pada tahap paling awal, konselor perlu menyaring anggota kelompok berdasarkan kecocokan individu dengan tujuan kelompok. Proses tersebut dapat dilakukan dengan wawancara dan evaluasi, atau dalam praktiknya konselor sekolah dapat melakukan observasi di dalam kelas. Adapun individu yang mendapat rekomendasi dari guru lain maupun individu yang mengajukan diri mereka sendiri perlu melakukan tahapan wawancara. Setelah proses tersebut terlewati, agar perjanjian kontrak terasa lebih formal lagi, konselor perlu memberi inform consent pada individu yang berisi data diri mereka, aturan-aturan yang berlaku, dan diakhiri dengan perjanjian kerjasama yang menandakan bahwa mereka bersedia memenuhinya. Pada form tersebut, konselor bisa mencantumkan feedback apa saja yang akan mereka terima apabila dilanggar.

\section{Kesimpulan}

Kesimpulan yang diperoleh dari penelitian ini adalah konselor memiliki tanggung jawab etis untuk menjelaskan makna kerahasiaan di dalam konseling kelompok. Asas kerahasiaan menjadi penting mengingat etika profesi konselor cukup memberi perhatian lebih perihal privasi konseli, sebab akan menyangkut pada kenyamanan dan keamanan dalam menerima layanan konseling. Dalam pelaksanaan konseling online, konselor bisa melakukan antisipasi tentang adanya kemungkinan pelanggaran yang tidak diinginkan dengan melakukan upaya seperti: (1) Melakukan wawancara dan evaluasi ketika membentuk kelompok, (2) Melakukan observasi secara mendalam saat memberi layanan klasikal di dalam kelas, (3) Mengelompokkan individu yang secara sukarela dan tidak sukarela mengikuti kegiatan kelompok, (4) Memberi inform consent yang berisi data diri, aturan yang berlaku, dan perjanjian kerjasama yang di dalamnya berisi tentang keamanan privasi dirinya dan anggota lain, (5) Anggota membubuhkan tanda tangan di bawah pernyataan tentang hal apa saja yang akan mereka terima apabila tidak memenuhinya.

\section{Saran}

Berdasarkan hasil penelitian ini agar guru BK memiliki kemampuan dan keinginan belajar yang kuat terkait perkembangan teknologi serta kemampuan adaptasi yang tinggi agar layanan yang diberikan tetap optimal di tengah situasi pandemi tanpa melanggar etika profesi yang telah ada.

\section{Daftar Pustaka}


Ardi, Z., \& Putra, R. M. (2017). Ethics And Legal Issues In Online Counseling Services: Counseling Principles Analysis . Jurnal Psikologi Pendidikan \& Konseling, Vol. 3, No. 2, 15-22.

Corey, G., Corey, M. S., \& Callanan, P. (2011). Issues and Ethics in the Helping Professions. United States of America: Brooks/Cole Cengange Learning.

Duniawati, D. S., Muksin, U., \& Lukman, D. (2020). Model Konseling Online Ibunda.Id. Jurnal Bimbingan, Penyuluhan, Konseling, dan Psikoterapi Islam Volume 8, Nomor 1, 1-18.

Gozali, A. (2020). LAYANAN BIMBINGAN DAN KONSELING BERBASIS TEKNOLOGI INFORMASI PADA MASA PSBB (PEMBATASAN SOSIAL BERSKALA BESAR). Jurnal Bimbingan dan Konseling Pendidikan Islam Volume 1, Nomor 2, 36-49.

Haryati, A. (2020). Online Counseling Sebagai Alternatif Strategi Konselor dalam Melaksanakan Pelayanan E- Counseling di Era Industri 4.0. Bulletin of Counseling and Psychotherapy Vol. 2, No. 2, 27-38.

Humphreys, K., Winzelberg, A., \& Klaw, E. (2000). Psychologists' Ethical Responsibilities in Internet-Based Groups: Issues, Strategies, and a Call for Dialogue. Psychology: Research and Practice, Vol. 31, No. 5, 493-496.

Koh, M. H., \& Hill, J. R. (2009). Student Perceptions of Group Work in an Online Course: Benefits and Challenges. Journal of Distance Education, Vol. 23, No. 2, 69-92.

Kozlowski, K. A., \& Holmes, C. M. (2014). Experiences in Online Process Groups: A Qualitative Study. The Journal for Specialists in Group Work, 39:4, 276-300.

Masi, D., \& Freedman, M. (2001). The Use of Telephone and On Line Technology in Assessment, Counseling, and Therapy. Employee Assistance Quarterly, 16:3, 49-63.

Noviyanti, N. I. (2020). Instagram Social Media As Guidance And Counseling Media Based On Technology . International Journal of Applied Guidance Counseling, Vol. 1, No. $1,16-19$.

Prabawa, A. F. (2015). BISTRI VIDEOCONFERENCE BERBASIS WEBSITE UNTUK LAYANAN KONSELING MAYA (CYBERCOUNSELING). Malang: Seminar Nasional Teknologi Pendidikan UM.

Prabawa, A. F., Ramli, M., \& Fauza, L. (2018). Pengembangan Website Cybercounseling Realita untuk Meningkatkan Keterbukaan Diri Siswa Sekolah Menengah Kejuruan. Jurnal Kajian Bimbingan dan Konseling, 3(2), 59-68.

Prahesti, Y., \& Wiyono, B. D. (2017). PENGEMBANGAN WEBSITE KONSELING ONLINE UNTUK SISWA DI SMA NEGERI 1 GRESIK. Jurnal BK UNESA, 144154.

Syamila, D., \& Herdi. (2021). Konseling Online: Pemanfaatan Teknologi dalam Layanan Konseling Kelompok di SMP Global Islamic School Jakarta . Jurnal Paedagogy, Vol. 8, No. 4.

Tsan, J. Y., \& Day, S. X. (2008). Personality and Gender as Predictors of Online Counseling Use. Journal of Technology in Human Services, 39-55.

Walz, G. R., \& Kirkman, C. (2004). CyberBytes Highlighting Compelling Uses of Technology in Counseling. Greensboro: CAPS Press. 